\title{
Comunicação
}

[Communication]

\section{Manutenção in vitro de células IDE8 em dois tipos de soro bovino}

[In vitro maintenance of IDE8 cells using two types of bovine serum]

\author{
C.V. Bastos ${ }^{1}$, M.M.C. Vasconcelos $^{2}$, M.F.B. Ribeiro ${ }^{2}$, L.M.F.Passos ${ }^{1} *$ \\ ${ }^{1}$ Escola de Veterinária - UFMG \\ Caixa Postal 567 \\ 30123-970 - Belo Horizonte, MG \\ ${ }^{2}$ Departamento de Parasitologia - ICB - UFMG
}

Dentre os fluidos biológicos que determinam o sucesso de uma cultura de células fora de um organismo, o soro representa o de maior significância. A concentração ideal para garantir o crescimento ótimo de uma cultura pode variar de 5 a $20 \%$ de soro (Maurer, 1986).

A principal função do soro é fornecer fatores hormonais que estimulem o crescimento celular e suas funções, fatores de adesão e expansão e transporte de proteínas carregadoras de hormônios, minerais, lipídeos etc. O papel mais importante do soro está na promoção de adesão e expansão de uma linhagem através de fatores como o colágeno, fibronectina, dentre outros (Maurer, 1986).

Dentre as principais desvantagens do uso do soro em cultivo de células estão o aumento do risco de contaminação por vírus, fungos e micoplasmas e seu elevado custo, principalmente no caso do soro fetal bovino.

O cultivo de células de carrapatos alcançou o estabelecimento da sua primeira linhagem 30 anos atrás (Varma et al., 1975) e, hoje, as linhagens estabelecidas são valiosas ferramentas, sendo utilizadas para a propagação de muitos patógenos.

Segundo Bell-Sakyi (2004a) há aproximadamente 13 linhagens celulares estabelecidas de sete gêneros de carrapatos de importância médica e veterinária.

A IDE8 é uma linhagem contínua de células embrionárias originadas do carrapato Ixodes scapularis. Estabelecida em 1994, ela é mantida em meio L-15B (Leibovitz), com $\mathrm{pH}$ próximo de 7,2 , suplementado com $5 \%$ de soro fetal bovino (SFB), $10 \%$ de caldo de triptose fosfatada (CTF) e $0,1 \%$ de lipoproteína bovina concentrada (LBC).

A temperatura de manutenção é de $30 \pm 2^{\circ} \mathrm{C}$ (Munderloh et al., 1994), e o meio é trocado semanalmente, o que permite a aderência e multiplicação das células, dobrando a população em 3-5 dias, com densidade de aproximadamente $5 \times 10^{6}$ células/ml (Munderloh et al., 1996).

Vários patógenos, transmitidas ou não pelo $I$. scapularis, já foram estabelecidos em IDE8 como a riquétsia Anaplasma marginale que infecta eritrócitos bovinos (Munderloh et al., 1996; Blouin e Kocan, 1998) e Ehrlichia ruminantium causadora de cowdriose ("Heartwater") Bell-Sakyi (2004b).

A produção de antígenos a partir de células cultivadas de carrapatos comparada à produção por infecção experimental de animais susceptíveis é mais simples e, em geral, de menor custo de manutenção. Alguns sistemas de cultivos de células de carrapatos possibilitam o

Recebido em 9 de fevereiro de 2006

Aceito em 21 de dezembro de 2006

* Autor para correspondência (corresponding author)

E-mail: lygia@vet.ufmg.br 
cultivo de antígenos, livres de membranas animais ou patógenos, para serem utilizados em testes de diagnóstico (Saliki et al., 1998; Rodgers et al., 1998) e no desenvolvimento de vacinas (Blouin et al., 1998; Kocan et al., 2001; de la Fuente et al., 2002).

Este trabalho teve o objetivo de avaliar condições de manutenção e expansão da linhagem IDE8 in vitro utilizando duas marcas de soro fetal bovino (importada e nacional).

A linhagem IDE8 utilizada foi gentilmente cedida pela Dra U.G. Munderloh (University of Minnesota, USA) na forma de células vivas em suspensão, que foram mantidas nas condições preconizadas por Munderloh et al. (1994).

Duas marcas de SFB, uma importada ${ }^{1}$ e outra nacional $^{2}$, foram avaliadas quanto ao desempenho proporcionado às culturas de IDE8. As células foram cultivadas em placas de 24 orifícios $^{3}$, contendo $1 \mathrm{ml}$ de meio completo, sendo quatro réplicas para cada condição. Em todos os orifícios os meios eram trocados semanalmente e subculturas eram realizadas quinzenalmente.

Avaliou-se a viabilidade celular pelo método de exclusão do azul de Tripan, que baseia no fato de que esse corante, não sendo lipofílico, normalmente não penetra nas células, o que passa a ocorrer no caso de ruptura da membrana plasmática, indicando, a morte celular.

De cada cultura de células, $50 \mu 1$ da suspensão obtida após desorganização da monocamada para a realização de subculturas foram colhidos e colocados em um tubo de hemólise contendo $450 \mu 1$ de azul de Tripan $0,3 \%$ e, em seguida, homogeneizados. As células foram visualizadas em câmara de Neubauer e o percentual de viabilidade calculado pelo resultado do número de células viáveis (vivas), dividido pelo número total de células contadas (vivas e mortas), multiplicado por $100 x$.

A morfologia celular foi avaliada pela observação das culturas e microscópio invertido ${ }^{4}$

\footnotetext{
${ }^{1}$ Sigma ${ }^{\circledR}$

${ }^{2}$ Cultilab ${ }^{\circledR}$

${ }^{3}$ Cell Wells - Corning ${ }^{\circledR}$

${ }^{4}$ ausJENA ${ }^{\circ}$
}

e de impressões confeccionadas em lâminas de vidro a partir de uma amostra de cada cultura de IDE8 pela centrifugação de $50 \mu 1$ de suspensão das células a $67 \mathrm{xg}$ por um minuto em Citospin $\AA^{5}$. As lâminas foram fixadas em metanol PA (duas vezes por 10 minutos), coradas em solução de Giemsa $8 \%$ por 30 minutos, lavadas, secas e examinadas em microscópio óptico (1000x).

Utilizou-se o coeficiente de variação (CV) reduzido, provavelmente $<5 \%$, para comparar a viabilidade celular por meio do qui-quadrado, baseado em Sampaio (2002). Em algumas comparações, obteve-se apenas um grau de liberdade; nesses casos utilizou-se o cálculo do qui-quadrado ajustado $\left(\chi_{\text {AJ }}^{2}\right)$.

O desempenho das culturas de IDE8 cujo meio foi suplementado com soro importado foi semelhante ao desempenho observado nas culturas mantidas com soro nacional durante os primeiros 45 dias de cultivo. Em ambas as condições de suplementação não foram detectadas contaminações durante o cultivo.

Nos primeiros 15 dias de cultivo, os dois grupos de culturas apresentaram pequena queda na percentagem de células viáveis, possivelmente pela adaptação inicial em placas, pois antes de se iniciar o experimento a cultura de IDE8 estava sendo mantida em tubos de $2 \mathrm{ml}$. Nos 30 dias seguintes, as curvas de desempenho das culturas com SFB nacional e importado continuaram paralelas e próximas em valores de percentagem de viabilidade sem diferenças estatisticamente significativas $(\mathrm{P}<0,05)$ (Fig. 1). Comportamento semelhante foi observado em todas as subculturas feitas a partir das culturas que iniciaram o experimento, observando-se que estas passagens com soros importado e nacional continuaram com valores próximos de viabilidade (Fig. 2). Portanto, o uso dos dois soros de distintas origens não resultou em diferenças estatisticamente significativas nas percentagens de viabilidade das culturas em passagens posteriores.

Pelo elevado padrão de controle de qualidade, os soros produzidos por empresas internacionais ganharam credibilidade, embora tenham custos extremamente altos, quando comparados aos

${ }^{5}$ Modelo 248 - FANEM 
nacionais. Muitos sistemas de cultivos não se adaptam à suplementação com SFB nacionais, tornando inviável a manutenção de certas linhagens, pois o soro fetal bovino importado constitui o componente mais caro do sistema. Além disso, deve-se ressaltar que há limitações de importação de produtos de origem animal, a exemplo do que ocorre com componentes biológicos oriundos de ruminantes de países com registros de encefalopatia espongiforme bovina (EEB), ou de outros países considerados de risco pela Secretaria de Defesa Agropecuária (BRASIL, 2004). No presente trabalho, o sucesso da suplementação da IDE8 com SFB nacional possibilita, portanto, sua manutenção in vitro nas condições brasileiras com custos muito menores e com facilidades práticas.

Concluiu-se que a linhagem IDE8 pode ser mantida em cultivos contínuos no Brasil sendo suplementada com SFB de marca nacional de boa procedência em substituição à suplementação com SFB importado, sem comprometimento da viabilidade celular.

Palavras-chave: bovino, IDE8, cultivo in vitro, células de carrapato, soro fetal bovino

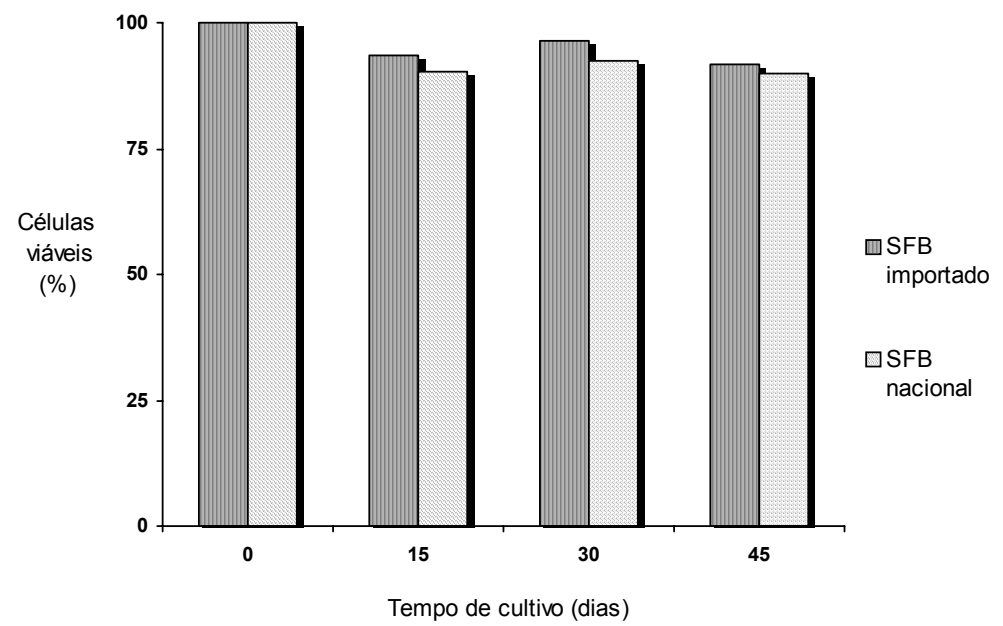

Figura 1. Valores da viabilidade in vitro de culturas de células IDE8, segundo a origem do soro fetal bovino (SFB) e o tempo de cultivo.

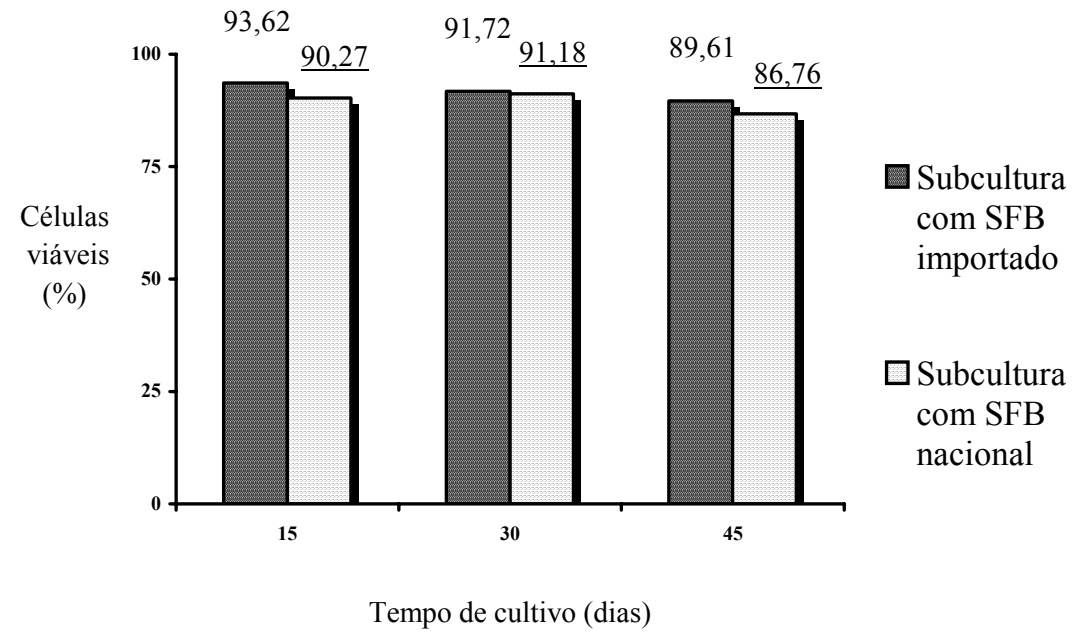

Figura 2. Valores da viabilidade in vitro de subculturas de células IDE8 segundo a origem do soro fetal bovino (SFB) e o tempo de cultivo. 


\begin{abstract}
The present study had the objective of defining the culture conditions, optimizing the maintenance and expansion of an IDE-8 cell line in Brazil, with the aim to propose its use as a model for in vitro infection and multiplication of Brazilian strains of rickettsia and other hemoparasites. The supplementation of IDE-8 cells with two distinct fetal bovine sera (a Brazilian and an imported) was evaluated. Culture media were changed weekly and subcultures were carried out every 15 days. The development of cultures and subcultures was evaluated by the percentage of viability and cellular morphology. The results indicate that the imported SFB can be replaced by the Brazilian $S F B$ one, as no significant differences $(P<0.05)$ were seen among culture viabilities.
\end{abstract}

Keywords: bovine, IDE8, in vitro culture, tick cells, fetal bovine serum

\section{REFERÊNCIAS BIBLIOGRÁFICAS}

BELL-SAKYI, L. Epidemiology of heartwater in Ghana and growth of Ehrlichia ruminantium in tick cell lines. 2004a. 205f. Tese (Doutorado) Faculdade de Medicina Veterinária, Utrecht University.

BELL-SAKYI, L. Ehrlichia ruminantium grows in cell lines from four Ixodid tick genera. $J$. Comp. Pathol., v.130, p.285-293, 2004 b.

BLOUIN, E.F.; KOCAN, K.M. Morphology and development of Anaplasma marginale (Rickettsiales: Anaplasmataceae) in cultured Ixodes scapularis (Acari: Ixodidae) cells. J. Med. Entomol., v.35, p.788-797, 1998.

BRASIL. Instrução Normativa $\mathrm{n}^{\circ} 7$ de 17 de março de 2004. Faz proibições quanto à importação de ruminantes e produtos derivados de países com registros de casos de encefalopatia espongiforme bovina. Ministério da Agricultura, Pecuária e Abastecimento, Diário Oficial da União, 18 de março de 2004, seção 1, p. 3.

de la FUENTE, J.; KOCAN, K.M.; GARCIAGARCIA, J.C. et al. Vaccination of cattle with Anaplasma marginale derived from tick cell culture and bovine erythrocytes followed by challenge-exposure with infected ticks. Vet. Microbiol., v.89, p.239-251, 2002.

KOCAN, K.M.; HALBUR, T.; BLOUIN, E.F. et al. Immunization of cattle with Anaplasma marginale derived from tick cell culture. Vet. Parasitol., v.102, p.151-161, 2001.

MAURER, H.R. Towards chemically-defined, serum-free media for mammalian cell culture. In:
FRESHNEY, R.I. Animal cell culture: a pratical approach. Oxford: IRL, 1986. cap. 2, p.13-30.

MUNDERLOH, U.G.; LIU, Y. WANG, M. et al. Establishment, maintenance and description of cell lines from the tick Ixodes scapularis. J. Parasitol., v.80, p.533-543, 1994.

MUNDERLOH, U.G.; BLOUIN, E.F.; KOCAN, K.M. et al. Establishment of the tick (Acari: Ixodidae)-borne cattle pathogen Anaplasma marginale (Rickettsiales: Anaplasmataceae) in tick cell culture. J. Med. Entomol., v.33, p.656664, 1996.

RODGERS, S.J.; SALIKI, J.T.; BLOUIN, E.F. et al. The development of a semi-automated latex agglutination test for the detection of antibodies to Anaplasma marginale using a cell culturederived antigen. Ann. N. Y. Acad. Sci., v.849, p.282-292, 1998.

SALIKI, J.T.; BLOUIN, E.F.; RODGERS, S.J. et al. Use of tick cell culture-derived Anaplasma marginale antigen in a competitive ELISA for serodiagnosis of anaplasmosis. Ann. N. Y. Acad. Sci., v.849, p.273-281, 1998.

SAMPAIO, I.B.M. Estatística aplicada à experimentação animal. 2.ed. Belo Horizonte: FEPMVZ, 2002. 265p.

VARMA, M.G.R.; PUDNEY, M.; LEAKY, C.J. The establishment of three cell lines from the tick Rhipicephalus appendiculatus (Acari: Ixodidae) and their infection with some arbovirusis. J. Med. Entomol., v.11, p.698-706, 1975. 